DOI: $\underline{10.20472 / E S .2015 .4 .1 .001 ~}$

\title{
MAINSTREAM VERSUS HETERODOX VIEW ON FINANCIAL INNOVATION
}

\section{MARTIN JANICKO}

\begin{abstract}
:
There is much controversy surrounding something what is conventionally called "financial innovation". Yet, it should be in any case seen as a relatively substantial element in the functioning of modern economies. However, its general impact should be assessed from quite different perspectives, depending on its particular behavior, and subsequently, the role it plays in an economy. In terms of economic fluctuations, financial innovations are frequently assessed based on the cycle amplitude. The amplitude may typically be determined by efforts to evade a regulatory framework set by a central authority in the country. Most importantly, this contribution follows either Post Keynesian or Regulation School logic, trying to clarify business cycle volatility with respect to the intensity of innovative activities in the financial sector. At the same time, it also strives to specify the most important standpoints of contemporary mainstream economics. Its main conclusion is that higher intensity of financial innovation usually leads to a higher volatility of the business cycles, namely due to excessive pessimistic or optimistic sentiment and influx of supplementary credit. Additionally, at times it may also lead to so called self-fulfilling prophecy, which itself contributes to the major vector direction of the economy.
\end{abstract}

\section{Keywords:}

financial innovation; mainstream economics; Regulation School; Post Keynesian economics

JEL Classification: G01, G28, E32

\section{Authors:}

MARTIN JANICKO, Vysoká škola ekonomická v Praze, Czech Republic, Email: martin.janicko@vse.cz

\section{Citation:}

MARTIN JANICKO (2015). Mainstream Versus Heterodox View on Financial Innovation. International Journal of Economic Sciences, Vol. IV(1), pp. 1-24., 10.20472/ES.2015.4.1.001

Certain parts of the article have been already published within the author's dissertation thesis at the University of Economics in Prague, defended in late 2013. 


\section{INTRODUCTION}

In recent decades the problems of financial stability and financial innovation have been growing in importance, both for economic scientists and for economic policy makers. Similarly, the impact of financial/nominal variables on the behavior of real ones has substantially increased due to a number of newly created proliferation channels between the financial and real sectors of the economy. Further, massive deregulation in developed economies ${ }^{1}$, starting from the late 1980 s, has brought about many challenges for policy makers in terms of financial market regulation and control, the overwhelming majority of which have not yet been satisfactorily addressed.

This deregulation, coupled with the overall liberalization of capital flows and the dominance of conventional free-market wisdom in general, has involved most economic sectors that have had at least partial linkages to financial products, instruments and/or tools. Similarly, it has involved economic sectors where the need for capital endowment is comparably higher, i.e. those often representing core industries of the economy. Finally, an unprecedented level of financial innovation activity, which is typical mostly of the 1990s and the first decade of the new millennium, has only exacerbated the whole existing problem, all at once requiring new forms of economic and financial education. ${ }^{2}$

Hence, it is no surprise that such evolution has led to a reaction on the part of theoretical economics. Almost all economic schools of thought have responded to the new challenges, using not only different methodologies, but also different assumptions. Some of these schools have even based a very important part of their raison d'être on instability issues stemming from this evolution. Among them is not only the notorious Post Keynesian School, but also the "French" Regulation School. However, many other schools have exploited the abrupt changes in the financial world to support, amend and/or adjust their own theories. This has been especially true for Neo Keynesians, "Austrians", (Neo) Marxists, Real Business Cycle theorists ${ }^{3}$, and (Neo) Monetarists.

As far as recent research is concerned, questions about financial stability have been put forth particularly by Post Keynesian thinkers, especially those from the "North American branch". Among them, H. Minsky, P. Davidson, L. Wray, B. Moore, M.

\footnotetext{
${ }^{1}$ The term "developed economies" might not always be perceived as the most pertinent one. As a consequence, a number of economists have an inclination to use different terms, such as "mature economies", "advanced economies" or even "industrialized economies". In this thesis, the terms "developed economies", "mature economies" and/or "advanced economies" are used interchangeably in order to refer to the group of the wealthiest countries in the world in terms of real production. Perhaps the closest reference group could be thought of as member countries of the OECD.

${ }^{2}$ The popular term financial education conventionally refers to the spread of what is deemed essential financial knowledge in the general public. It might sometimes be confused with higher financial education, which has experienced a rapid expansion over recent years. By contrast, the expansion of higher financial education appears not to entirely follow the situation in the labour market.

${ }^{3}$ Conventionally abbreviated in economic literature as "RBC", which is also the case in this text. Sometimes, however, "RBCT" can be seen as well.
} 
Lavoie $^{4}$ and L.-P. Rochon ${ }^{5}$ deserve particular mention. Their works dedicated to the financial instability of the modern capitalist system and the efficacy of regulatory frameworks are well known in the whole economic academic sphere. Many other economists such as Scheinkman and Weiss (1986), B. Friedman (1986), Greenwald and Stiglitz (1993), Gertler ${ }^{6}$ and Gilchrist (1994), and Kiyotaki and Moore (1997) typically concentrate on credit cycles, financial cycles, as well as specific sector bubbles. ${ }^{7}$ Similarly, a link between purely financial and macroeconomic variables is being studied in more detail by an increasing number of economists. A large part of the research conducted so far has confirmed that financial variables are ever more dependent on macroeconomic ones and vice versa. Put differently, the causality involved can now apparently be encapsulated as a "two-way" form, which was strikingly amplified and demonstrated during the period of acute financial turmoil in $2007^{8}$

Financial innovation is one of the modern lubricants of this proliferation. It is typically understood as the development of new financial products and processes, acquiring different features in terms of liquidity and their relationship to the regulatory framework of a country/economy. Clearly, there are also some financial innovations that may not have any link to the regulatory framework whatsoever. These innovations are typically products that generally increase the velocity of money, such as credit/debit cards, checks, or ATMs. (Schrieder and Heidhues, 1995)

Furthermore, Schiller (2009) regards financial innovation as a necessary element for the functioning of the capitalist system. Its complexity may not be detrimental given that complexity has been increasing everywhere. Schiller enumerates innovative elements that function in the economy and are treated as beneficial or at least harmless to the economic system (pension annuities, the refinancing of mortgages, etc.) In recent years, however, financial innovation has mostly been seen in the form of different types of securitization ${ }^{9}$, which typically signifies the risk dispersion of an

\footnotetext{
${ }^{4}$ The "North American" branch is essentially perceived as the more "moderate" one, with very benign links to the radial economics represented for the most part by Marxists, Neo Marxists, radical socialists, feminists and radical institutional economists. Sometimes, even "Sraffians" qualify as radical economists, although the stream is relatively narrow and mostly based on Marxism.

${ }^{5}$ It is worth stressing, however, that Rochon is commonly treated as a circuitist. The circuitists, as opposed to orthodox Post Keynesians, believe that it is not the predominantly existing institutional framework which makes money endogenous, but that money is endogenous as such - or per se. This understanding is conventionally called money ab ovo and the circuitists like to distinguish themselves from Post Keynesians, especially in this very nature of money endogenity, despite their common or very similar standpoints regarding other attributes of modern economies. (Rochon, 2003)

${ }^{6}$ Gertler alone wrote several important empirical papers devoted to financial capacity and economic activity and he admittedly inspired many financial economists in the 1990s.

${ }^{7}$ In their contributions, the mentioned authors do not necessarily follow any specific stream of economic thought and often stick to a rigorous empirical approach.

${ }^{8}$ The financial background of the crisis has been confirmed on a number of occasions. For instance, the so-called de Larosière Report finds the reasons for the crisis notably in excess liquidity, financial innovation, and low interest rates. According to the mentioned Report, "...liquidity and low interest rates have been the major underlying factor behind the present crisis, but financial innovation amplified and accelerated the consequences of excess liquidity and rapid credit expansion. Strong macroeconomic growth since the mid-nineties gave an illusion that permanent and sustainable high levels of growth were not only possible, but likely." (de Larosière et al., 2009)

${ }^{9}$ Securitization is conventionally defined as the transformation of various liquid assets into some type of security. The assets used may or may not have common denominators, may or may not be linked to each other, or may or may not have sensitivity resembling the behaviour of other assets.
} 
asset and its attachment to assets with no direct link to each other in terms of character, maturity and/or currency denomination.

According to Merton (1992) we can distinguish six roles and functions most typical of financial innovation:

(1) Resource movement in time and space.

(2) Resource pooling.

(3) Diversification and risk management.

(4) Information improvement for the improvement of decision-making processes.

(5) Moral hazard and information asymmetry resolution. ${ }^{10}$

(6) Economic exchange enhancement. ${ }^{11}$

Historically, financial innovations have played an important role in the US economy almost from the beginning of the industrial revolution. They are linked to the development of capital and money markets in the US, those typical of the second half of the $19^{\text {th }}$ century, which resulted from the rapid development of industrialproduction capitalism. Although the situation and context then were completely different, banks and financial institutions were also capable of seeking new profit opportunities through the offer of diversified financial assets. Furthermore, their second most important motivation lays in increasing or at least maintaining their respective market share and keeping the overall expansion dynamics of the financial sector in motion. (Partnoy, 2009)

This was accidently one of the reasons that led to the development of diverse forms of financial capital. This kind of development has, at the same time, provoked various criticisms, notably from Marxists, but also non-Marxist economists, criticism which was in fine directed against capitalism itself. A typical example of such critiques can be found in Rudolf Hilferding's Financial Capital ${ }^{12}$, first published in 1910 (Hilferding, 1910 (1970)). Hilferding's analysis of so-called fictional capital and the concomitant transfer of private equity to stocks can easily be considered as a

\footnotetext{
${ }^{10}$ Interestingly enough, many financial innovations are typical moral hazard instruments. A good example is the credit default swaps - commonly abbreviated as CDS - that can easily be used without the necessity of even acquiring the concerned pool of assets. In other words, the buyer may not have any interest in the flawless functioning of the third party upon whose solubility the swap is actually issued. Many other good examples can certainly be found for other types of innovation products, and the question normally arises whether or not this is the intrinsic characteristic of the product or whether, in the course of time, such a product has turned into a different type. Similar argumentation can be found for instance in Švihlíková (2010).

${ }^{11}$ By the enhancing of economic exchange we mean primarily the streamlining of economic transactions due to funds being more readily available. It remains questionable what is still an innovation and what is simply related to debt-based economic exchange.

12 Although Hilferding took over a large portion of Marx's theory, his presence in the Second International on the Austrian/German social-democratic side classified him as a typical socio-democratic reformist. On this account he was mainly criticized by Lenin and Trotsky in a very similar manner to the way in which Karl Kautsky was criticized for his arguments concerning imperialism.
} 
precursor analysis to the financial innovation critiques of the 1980s, 1990s and 2000s.

For the most part, terms such as financial capital or financial bourgeoisie are the ones very often used in the beginning of the $20^{\text {th }}$ century. Likewise, they are closely related to the importance of the financial sector in the capitalist economy, including its interconnection with industrial capital, ultimately leading to the creation of conglomerates. According to Hilferding (1910 (1970)), the further expansion of conglomerates suppresses the productive capacity of economies, and industrial businesses find themselves incarcerated by the financial sector and its own interests. The consequent imbalances between the financial and real sectors of the economy were propelled by the centralization and consequent industry concentration that had grown apace in the late $19^{\text {th }}$ century and in the beginning of the $20^{\text {th }}$ century. This was caused inter alia by the existence of a different production pattern in the capitalist economy, when capital turnover time soared (compared to previous decades), and, therefore, substantially empowered banks and financial institutions. Credit provision and financial products began to play their indispensable part in the system, since they were helping to be able to react to the modified production cycle. The beginning of the $20^{\text {th }}$ century thus marks the veritable beginning of financial and banking sector power vis-à-vis the production side of the economy.

The rest of this first article is organized as follows: in the first chapter, financial stability is discussed, especially in the context of financial and economic turmoil; in the following chapter, the Regulation School and its contribution to economics is presented; the third chapter analyzes the effects of financial innovation on the economy and the role it plays; the fourth chapter sketches out the effects of financial innovation on the business cycle; and the concluding chapter offers some tentative insights into economic policy challenges regarding financial stability.

\section{FINANCIAL STABILITY: PRE-CRISIS AND POST-CRISIS CONTEXT}

Financial stability is not easy to measure, as it is a very complex and interdependent variable. Many economists and policy makers have constantly tried to set out what financial stability means, typically without reaching any satisfactory conclusion or even consensus. However, surprisingly enough, the term has become familiar to many people in modern societies, as the frequency of its use has mushroomed in general media. Such a development might be ascribed to the many economic policy attempts to react to the increased importance of financial intermediaries and financial institutions in national economies as well as outside them. ${ }^{13}$

\footnotetext{
${ }^{13}$ Typical examples of economic policy reaction include the Basel regulations for capital adequacy in all their recently developed formats. The Basel requirements have, since their introduction, been commonly perceived as one of the measures targeting the preservation of financial stability.
} 
Furthermore, financial stability is therefore sometimes defined in terms of financial "instability", i.e. by stating what financial stability is not rather than what financial stability really is. This then translates into a negative definition, which may become particularly useful to policy makers as it paves the way for many discretionary measures and decisions. Alas, it also seems evident that a number of authors do not pay much attention to the relatively subtle difference between financial stability and macroeconomic stability. These terms should not normally coincide, as they refer to different types of variables. On the other hand, needleless to say, the two types of stability are interrelated and usually also correlated. ${ }^{14}$ Moreover, the number and heterogeneity of agents entering the functioning of financial transactions make the matter very complex and sophisticated. This is not only true for private and commercial agents but also for other involved players, such as governmental institutions and international and non-governmental organizations. The complexity arose because of the overlapping of the financial with real sectors, which occurred as soon as multinational corporations penetrated both of these spheres.

In the contemporary academic world there is a widely-shared view about the necessity of addressing urgent financial stability issues. For example, Ferhani (2010) argues that the importance of financial stability is now more emphasized than ever before, as financial turmoil has intrinsically affected the balance sheets of many central banks all over the world. ${ }^{15}$ Likewise, because exchange rates and inflation are of primary interest to most central banks in developed economies, financial stability is a crucial variable that should never be underestimated or marginalized. Other economists point to the fact that the methodological perception of financial stability has changed as a consequence of the recent financial and economic turmoil. For instance, Borio (2011) states that prior to the crisis "ensuring the liquidity of institutions was primarily the task of (retail) deposit insurance schemes, aimed at avoiding depositor runs, coupled with central bank emergency liquidity assistance at times of stress", while recently "the complete seizure of the interbank market and the reach of the gridlock in securitised credit markets, well beyond the banking sector, took observers and policymakers by surprise. This prompted huge interventions by central banks, supplying funding and purchasing assets on an unprecedented scale.

\footnotetext{
${ }^{14}$ The intensity of correlation differs according to the country taken: in developed countries, bigger fluctuations in financial stability may or may not cause macroeconomic stability to be undermined. In developing and/or emerging economies, the relation is closer and the lags are shorter. (Gai, Kapadia, Millard, and Perez, 2008)

${ }^{15}$ Further, one could certainly single out a number of proxies and/or operational variables that may be used for its measurement. These have been progressively elaborated on during the establishment of regulatory frameworks reflecting the changing economic reality and institutional setting in economies with a highly sophisticated financial sector. An array of such proxies can be found in the well-known Financial Stability Reports, conventionally used (and created) by central banks or by international financial and banking institutions. These reports typically pay attention to a number of indicators that respective policy makers deem as crucial. In this respect, according to Gadanecz and Jayaram (2009), "composite quantitative measures of financial system stability that could signal these conditions are intuitively attractive as they could enable policy makers and financial system participants to: (a) better monitor the degree of financial stability of the system, (b) anticipate the sources and causes of financial stress to the system and (c) communicate more effectively the impact of such conditions."

One can apparently argue that such an impact has been brought about by the debt crisis in the wake of the financial and economic one of 2008-2009. Nevertheless, central banks had got involved much earlier, most importantly with the creation of the ECB and the whole European Monetary System, which has contributed to mutual responsibility for financial stability in the European Union.
} 
And despite these widespread dislocations, by and large the payments and settlements infrastructure proved robust."16

Financial stability is conventionally regarded as the ability of the financial sector and its particles to absorb significant disturbances in financial markets. ${ }^{17}$ The absorption would most frequently be divided between the microeconomic and macroeconomic levels. The microeconomic level is presented through the possible impact on the decision-making processes of a number of individuals. Absorption at the micro level thus reflects the ability of individual agents to cope with liquidity and solvency issues. At the same time, another conceptual difference in the micro and macro approaches is in their perception of shocks the financial sector is exposed to.

While under the micro perspective, shocks are typically treated as purely exogenous (and subsequently the capacity of individual institutions to cope with them serves as a certain template for other cases), at the macro level many of these shocks are necessarily endogenous and become stronger with the behaviour of the sector itself. Obviously, in this case, absorption could be impaired simply by deviant reactions on the part of large players in the system, which would ultimately lead to contagion, which in turn would create another endogenous shock. (Borio, 2011) Likewise, absorption on the macro level usually reflects the ability of the whole system to overcome the mishaps stemming from mutual interconnectedness. It is also true that these absorption processes often follow discrete random walk representations and continuum stochastic dynamics ${ }^{18}$, which is why their ex ante deterministic modelling may be sometimes completely inappropriate.

Methodologically, the focus on micro indicators was predominant for many years from the 1970s. However, this approach, having become compromised in the run-up to the recent financial crisis and in the wake of it, seems to have been replaced by a more macroeconomic methodology. (Gadanecz and Jayaram, 2009; Borio, 2011) Equally, owing to the crisis, both institutional set-up as well as monetary activism now seem to be lauded as appropriate aspects which should be taken into consideration for the monetary policy authorities.

Consequently, relevant indicators, used conventionally in practice, should most realistically determine jeopardy for however defined financial stability may be logically divided into the ones called "alarm points" ${ }^{19}$, coming into play when first

\footnotetext{
${ }^{16}$ It may be worth noting that deposit insurance served as a typical starting point for a number of financial stability debates. Since the beginning of the recent financial turmoil, this topic has evaporated from any debate.

${ }^{17}$ Mainstream economic literature also sometimes distinguishes ex ante absorption and ex post absorption; provided that the consequences of the respective shocks are not clearly visible once the shock is inflicted. This may be caused by the existence of time lags.

${ }^{18}$ Here the Post Keynesian concept of non-ergodicity can apply as well. According to Post Keynesians, non-ergodicity is inherent in the majority of sophisticated economic processes. In this sense, optimization is difficult to apply. For clarity, an ergodic process can be defined as a random process $P(t)$, provided that the mean of the sample average asymptotically approaches the mean of the total.

${ }^{19}$ Sometimes also known as a signaling approach. According to Alessi and Detken (2009), for instance, the M1 gap and global private credit gap appear to be the best early indicators in recent times.
} 
signs of distress are recognized, and the ones with higher level of urgency. This is thoroughly followed and discussed by Alessi and Detken (2009), for example. Besides the stress tests performed on a system-wide basis, central authorities now tend to observe the accumulation of unusual credit expansions, or inexplicable asset price development and/or "the lack of mean-reversion in market measures of risk" (Borio, 2011). Clearly, when seeking appropriate stability indicators, one may always single out numerous associated financial stability approaches - those arising from theory, as well as those based on empirical analysis and best practice. ${ }^{20}$

The following table exhibits macroprudential and microprudential measures from the financial stability perspective. According to Ferhani (2010), these measures should be split evenly between central and subsidiary institutions of the financial supervision system so that conflicts of interest are avoided while keeping the "bigger picture" in existence.

Table 1: The Macro- and Micro-prudential perspectives compared

\begin{tabular}{|c|c|c|}
\hline & Macro-prudential & Micro-prudential \\
\hline Proximate objective & $\begin{array}{l}\text { Limit financial system-wide } \\
\text { distress }\end{array}$ & $\begin{array}{l}\text { Limit distress of individual } \\
\text { institutions }\end{array}$ \\
\hline Ultimate objective & Avoid output costs & $\begin{array}{l}\text { Consumer (investor/depositor) } \\
\text { protection }\end{array}$ \\
\hline Characterization of risk & $\begin{array}{l}\text { Seen as dependent on } \\
\text { collective behavior } \\
\text { ("endogenous") }\end{array}$ & $\begin{array}{c}\text { Seen as independent on behavior } \\
\text { of individual agents } \\
\text { ("exogenous") }\end{array}$ \\
\hline $\begin{array}{c}\text { Correlations and common } \\
\text { exposures across } \\
\text { institutions }\end{array}$ & Important & Irrelevant \\
\hline $\begin{array}{l}\text { Calibration of prudential } \\
\text { controls }\end{array}$ & $\begin{array}{l}\text { In terms of system-wide } \\
\text { risk; top-down }\end{array}$ & $\begin{array}{l}\text { In terms of risks of individual } \\
\text { institutions; bottom-up }\end{array}$ \\
\hline
\end{tabular}

Source: Own elaboration based on Borio, 2011

As seen from the above scheme, microprudential and macroprudential outcomes are, on the one hand, interrelated, but, on the other hand, can be frequently separated from each other (at least in some instances). The most important difference arises with an uneven level of spill-overs, whereby it is typically

\footnotetext{
${ }^{20}$ An illustrative example of this fact is the efforts of central banks in Europe to work on streamlining the indicators among themselves so that comparable results are yielded. Such an approach is, on the other hand, subjected to numerous inconveniencies related to country-bias sector specificity. (Gai, Kapadia, Millard, and Perez, 2008)
} 
recognized that proliferation channels are a very important factor in creating the methodological difference. According Borio (2011) himself, to each dimension presented "corresponds a source of system-wide financial distress. In the time dimension, the source is the procyclicality of the financial system, i.e. those mechanisms that operate within the financial system and between it and the macroeconomy and that can generate outsize financial cycles and business fluctuations. In the cross-sectional dimension, the source is the common exposures and interlinkages in the financial system that can result in joint failures of financial institutions by making them vulnerable to common sources of risk." Apparently, in an environment of free capital movement and floating currency regimes, any mentioned objectives also depend on the willingness to cooperate on the international scale, i.e. the ability to overcome the coordination problem.

The capacity of mature economies to self-equilibrate was put in doubt with the introduction of various forms of financial instability hypotheses - primarily, the one proposed by Minsky ${ }^{21}$. Long before the run-ups to the financial crises of the 1990s and 2000s, Minsky (1986) questioned the validity of prescriptions from the pen of standard economic theory adherents in case money is not only a veil for the real production sector. This is a very important presumption for modern economies. As Minsky correctly puts it, "the logical flaw in standard economic theory is that it is unable to assimilate capital assets and money of the kind that we have, which is created by banks as they finance capital asset production and ownership (...) Furthermore, the financing of investment and capital assets holdings within a modern banking environment makes the effective money supply endogenous." (Minsky, 1986) The approach that is being currently adopted tacitly follows Minsky's logic in that "financial instability is a normal functioning, internally-generated result of the behaviour of a capitalist economy." (Minsky, 1986)

To demonstrate how a pure change in costs alters financial patterns of entrepreneurs, Minsky also developed a sequence called cash box condition. Every economy or a unit economy has to make sure to be able to generate enough internal resources-cash inflows (CIF) or to have enough idle cash balances (IB) to meet its cash outflows (COF). Let net cash inflow (NCF) be the difference between CIF and COF. It follows that:

$$
\begin{aligned}
& I B+C I F \geq C O F \\
& I B+N C F \geq 0
\end{aligned}
$$

\footnotetext{
${ }^{21}$ Minsky (1985) himself argues, among other things, that equilibrating processes, which could be presented in barter economies, are not typical for developed capitalism. It is most importantly money and the financial sector that considerably undermine such processes due to the advanced complementarity of economic events. He says, however, that his hypothesis "...is more clearly a theory of the cyclical behaviour of a capitalist economy than the economic theory of other post-Keynesian economists. That is, the financial instability hypothesis leads to an investment theory of the business cycle and a financial theory of investment." (Minsky, 1985)
} 
Further, if NCF is lower than zero and there are no idle cash balances, the economic unit is considered illiquid. In case the situation lasts more periods of time, the agent can be even considered insolvent. In other words, before the agent discredits her reputation ${ }^{22}$ by adopting some kind of radical solution such as asset sales, or even runs into existential troubles, she will rather try to find new sources of liquidity. The cash box condition eloquently presents the way how an economy can find itself in a dangerous situation and what is its safety margin. In terms of accounting, sources of cash can be as follows: income transactions (from productive process), balancesheet transactions (interet, dividends, rents, and repayment on loans), and portfolio transactions (trading capital assets and financial instruments, sales of secured and unsecured debt, sales of assets).

Similarly, with respect to the level of analysis (individual, sectoral, or on the level of economy), the possible sources of funds and main net cash inflows may also be different. (Minsky, 1975) Importantly, in case the trade with securities can be a standard source of cash at the microlevel, at the aggregate level liquidation is simply not possible. Therefore, one possibility to measure financial fragility at the aggregate level is to analyse the ratio between income and balance-sheet generated cash flow. If agents need to make position, i.e. to meet balance-sheet commitments with portfolio-like financing, the more are the agents dependent upon the short-run financial conditions.

Also, Minsky correctly notes that the essential difference between financial and technological innovation is that the former has no "natural" limits: "The rate of increase of financial variables is limited only by ingenuity and acceptability. In a world with layering, the rate of change of financial variables really has no bounds. The ability of financial layering to increase the burden on the payments mechanism is one way in which the conditions necessary for financial instability can be generated." (Minsky, 1967)

As suggested earlier, the focus of central regulatory authorities on purely inflationrelated measures seems not to be sufficient anymore. A number of central banks succeeded in targeting inflation, which was pre-set to be goal number one in most developed countries, but financial stability was left behind. As the financial sector behaves distinctively pro-cyclically, when sometimes it even tends to create noninflationary bubbles, financial stability may not always be clearly visible to central banks if only price stability is being pursued. ${ }^{23}$ This in turn prevents monetary authorities from adopting more stringent measures, as these would lead to a major aggravation of already existing financial distress. (Ferhani, 2010)

\footnotetext{
${ }^{22}$ This is, according to Minsky, similar to a loss in net worth.

${ }^{23}$ A striking example of the non-inflationary bubble can be taken for instance from Japan in 1990 and again in 2007. Yet another non-inflationary bubble, with certainly less sophisticated and different assets and groups of assets, is the one of the 1929 Great Depression.
} 
In recent years, in terms of financial stability, the possibility of taking into account various asset prices has also been fervently discussed. Once again, mainstream economics has been rather opposed to such initiatives, judging them both inefficient and ineffective. The composite indicator, which would also reflect financial assets, i.e. assets that lie furthest from primary production, would also be able to capture potential bubbles. ${ }^{24}$ Such an indicator may be especially useful on a sector or industry basis, as the first potential signs of distress may be immediately recognized and any overheating extinguished. ${ }^{25}$

Nowadays, one of the most pressing questions is about which policy approach to adopt towards financial stability - particularly in terms of pro-active monetary policy. Should we still rely on more or less passive supervision and regulatory settings (despite their macroprudential nature), or should the authorities act as if the financial and economic crisis was, for them, a certain lesson learnt. The first signs of reorientation are being felt in terms of micro- vs. macro-prudence, as systemic risk, related to the collapse of the financial sector, has proved to be rather imminent. Still, for most economists, either recognition or even comprehension of the significant monetary character of modern industrialized economies is/would be undoubtedly a leap forward, since this fact was rarely acknowledged as a result of the Rational Expectations revolution in economics.

\section{THE REGULATION SCHOOL: A HETERODOX STREAM OF ECONOMIC THOUGHT}

The Regulation School ${ }^{26}$ is a relatively heterogeneous school of economic thought, standing clearly outside mainstream economic theory. ${ }^{27}$ The foundations of this school were laid in the mid-1970s, in the aftermath of the economic crisis caused by supply-side shocks, ultimately leading to stagflation, and resulting in a revolutionary shift in existing economic policies. The very primal theoretical basis of the School is to be found in the works of Michel Aglietta (Aglietta, 1976), Robert Boyer and Jacques Mistral (Boyer and Mistral, 1978) and Alain Lipietz (Lipietz, 1979). At the same time, the theory finds its theoretical backing in classical institutionalism - in Marxism and Keynesian economics - yet struggles to find its genuine raison d'être.

\footnotetext{
${ }^{24}$ Such an indicator has been promoted by many economists, mostly belonging to the Austrian School of economic thought. The construction of a composite price indicator is, nevertheless, a relatively complicated process, given the dynamics in the proliferation channels. Also, as the weights of different assets vary significantly over time, their incorporation would have to be swift and accurate. On the other hand, the usefulness of the construct for policy-makers may also be put into question.

${ }^{25}$ The above mentioned example of Japan in terms of price indicator and financial asset fluctuations may be found in Shiratsuka (1999), who is, himself, more skeptical about the appropriateness of such an intellectual construct.

${ }^{26}$ The Regulation School is frequently dubbed the French Regulation School due to its geographical origin and the nationality of most of its adherents. Alternatively, this stream of economic thought may also be in certain literature called the Theory of Regulation or the French Theory of Regulation.

${ }^{27}$ On these grounds the school has sometimes been accused of being overly eclectic, trying to cover too many topics from a number of different perspectives. Likewise, the theory used to be widely criticized for not using modelling and mathematical methods in its research. This has been to a certain extent reversed, particularly by Boyer (2000) and Aglietta (2004), who started to employ multi-equation systems in their analyses of accumulation regimes and the evolution of credit provision in the run-up to financial distress.
} 
The main field of interest of the Regulationists covers the development and regulatory tendencies of the capitalist system; they are especially interested in the process of replacing one regulatory system by another. Most of the exponents of the school regard this incongruity as a primary reason for the continuous reappearance of crises in the system. A more modern orientation of the theory includes (international) financial economics, credit provision, and the tensions such provision has created for industrialized and emerging economies.

It is for the most part Aglietta (1998) and Boyer (2000) who are primarily concerned with internal capitalist tensions, resulting in the ultimate "capitalism-by-capitalism" replacement. This is generally perceived as a special kind of dialectic, inherently present in whatever complex system exists. Following such logic, the Regulationists claim that ford-type capitalism was substituted by post-fordism. In other words, capitalism based on accumulation was evolutionarily replaced by a form of capitalism which, on the one hand, suppresses inflationary pressures, but, on the other hand, brings to bear constant downward pressure on wages and salaries in the name of effectiveness and efficiency enhancement. ${ }^{28}$ The inability of regulatory authorities to react when facing a newly established situation is subsequently one of the symptoms of distress and approaching crisis.

Also, the Regulationists write ironically about the advantages of financial liberalization for capital and investment, when arguments such as "a rising tide lifts all boats" are used. This kind of argument is, according to them, solely an effort to defend an uneven "cake cutting". ${ }^{29}$ Similarly, financial-innovative activities and credit availability have mostly been accompanied by waves of fraud, corruption and the concealment of information. A tendency to artificially lower risk perception has proved to be increasingly pervasive and more present than at any time in modern economic history. (Aglietta, 2008) Consequently, the neoliberal order manifested the ineffectualness of auto-regulation, which led to recurring crises in practically every part of the world. (Aglietta, 2008)

Likewise, the Regulationists drag attention to a number of accompanying phenomena, much related to deregulation and financial-innovative activities. Among them, for instance, is the revolutionary change in wealth distribution vis-à-vis the period from 1945 till 1970. According to Aglietta (2006), Amable (2005), Boyer (2000) and others, incomes were constantly under downward pressure while profits followed a rising trajectory. ${ }^{30}$ This kind of relationship provides evidence of higher capital remuneration at the expense of labour and was partially caused also by the

\footnotetext{
${ }^{28}$ The focus on the behavior of social classes in the economy may be conceived as one of the common elements of Post Keynesian and Regulationist thought. Post Keynesians, however, conventionally use such classification in more economic terms.

${ }^{29}$ The "cake" made by all factors of production. (Aglietta, 2006) This is also sometimes called the primary redistribution (versus the ad hoc or secondary redistribution of resources).

${ }^{30}$ Similar argumentation, in Czech, can be referred to in Janíčko and Janíčko (2012).
} 
inflow of cheap eastern labour into the system, abetting lower salaries in relation to capital gains.

According to the Regulationists, this also led to one of the roots of economic crisis the undermining of effective demand with respect to the accumulation regime. In order to stay in proximity of its equilibrium, the former has had to be artificially complemented by credit availability supporting current spending. Credit conditions have been, on top of this, enhanced by the extended offer of financial products. ${ }^{31}$ Most Regulationists assert that the real era of financial innovation existed in the 1980s and 1990s. In earlier periods, the banks had been typically forced to bear $100 \%$ of the risk of their operations and had had to create sufficient reserves. The situation changed dramatically in these two decades, most importantly as a result of innovative activities. These enabled investment banks in particular to transfer risks onto different and dispersed subjects. This in turn liberated more capital for the granting of further credit. (Aglietta, 2009; Boyer, Dehove, and Plihon, 2004)

The Regulationists consider the newly-created post-fordism, essentially based on financial integration, capital mobility and mutual interdependency, as highly unstable. As opposed to Post Keynesians, they try to look for the causes of such instability in the general inability to find a new modus vivendi between the financial sector, the real economy and the regulatory framework. In their understanding, a pioneering model is also the one based on creation of shareholder value, with low ratios of the equity employed. This brings in yet another destabilizing element into the capitalist system. On these grounds the adherents of Regulation theory support higher regulation of most financial transactions. This should, in fine, entail less risky behavior, and may significantly limit moral hazard and reduce real output growth based purely on the granting of credit and subsequent debt creation. (Aglietta, $2009)^{32}$

According to Aglietta (2009), system crises should not be regarded from any normative perspective. ${ }^{33}$ By means of these crises, capitalism is more able to adapt itself to a changing social framework and changing conditions, both swiftly evolving over time. From a longer-term view, system crises are only episodes in system evolution and contribute to its better functioning, as lessons are learned from imminent flaws. It is apparent that in spite of its temporary decrement due to its taking-up of a predominantly neoliberal doctrine, the Regulation School approach has recently been gaining in relevance. Moreover, as the awareness of financial and

\footnotetext{
${ }^{31}$ From this perspective, even the central banks in developed countries have been implicitly driven to conduct loose monetary policies.

${ }^{32}$ A very similar and, in some aspects, more elaborated explanation can be found e.g. in Holmström, 1979.

${ }^{33}$ By normative perspective the Regulationists mean the typical methodological division of economics between positive and normative.
} 
economic distress increases, the ideas of its exponents are now becoming even more popular with the general public, particularly in France. ${ }^{34}$

Even though (some of) their findings, arguments and reasoning appeared to be somewhat deviant in the 1990s global economic as well as academic worlds, they might now help us to better understand the causes and consequences that are just being felt as the economic crisis becomes a debt one. Even in this case, the financial sector has been able to profit from the actual situation by proposing and supporting reforms that are not necessarily beneficial for aggregate and social welfare. ${ }^{35}$ The effects of moral hazard in financial markets ${ }^{36}$ can lead to a different outcome in terms of the loanable funds market than would normally be expected.

The following part of the thesis concentrates on the rise of the financial sector, the existence of financial intermediaries, and, more specifically, the role of financial innovation in the modern era.

\section{AN EXAMPLE OF SELF-ENFORCING COLLUSION?}

It is commonly agreed that financial innovation are typically driven by competitive behaviour in the markets and first pioneered by large banks and financial institutions. Only then they are spread out onto the rest of the economy. The relationship between the rise of the financial sector and the intensity of innovative activities is relatively undisputable. Innovation played an insurmountable part for financial sector development - both in times of its expansion as well as in times when calls for streamlining/restructuring and/or cost cutting are heard the most. Clearly, the financial sector has many crucial roles for the very functioning of the modern economies and in the whole global economic network. As Krohn (2011) correctly states, "a central function of the financial system is to channel funds from savers to borrowers. This can be done through financial markets (direct finance) or through financial intermediaries (indirect finance). Such a role of financial markets realistically exists and may be predicted based on the division of labour theory. However, it may

\footnotetext{
${ }^{34}$ It seems worth mentioning that perhaps the two best known economists of this stream called attention to the possible mishaps capitalism would face in the foreseeable future already at the beginning of the new millennium (Aglietta and Orléan, 2002; Boyer, 2004).

${ }^{35}$ A good example is the case of pension reform - being intensively advocated by pension funds that often even create complex associations and/or other groups to defend their interests. Economic reasons for pension reform can be found for instance in Janíčko (2011) and/or more rigorously analysed in Kubíček (2008) and also in Loužek (2006). None of these authors discusses the behaviour of pension funds as such or endeavours to consider their behaviour as a possible outcome of power-seeking.

${ }^{36}$ For the sake of clarity, in the whole text, while avoiding any specific definitions, financial markets are regarded in conventional economic terms. This means that these are places where financial assets (including debts and interest bearing assets as well as shares and equities) and foreign currencies are traded and where specific roles could be assigned to various agents, such as individuals, public or private national institutions, as well as public international institutions and multinational financial corporations. Financial markets are often divided into nation-specific ones, regional ones, and the global one, according to their geographical designation.
} 
go out of hand when the financial institutions grow in importance or ultimately start to create their own "desirability".

The evolution of financial sector in the $20^{\text {th }}$ century would definitely not be easily predictable only one century back, since the then capitalism was based on different principles as well as on very different types of financing cycles. The same holds true for innovative activity that accompanied this evolution. Since the supply of credit belongs to the most important roles of financial institutions, innovative activities may help in pooling and channeling resources. ${ }^{37}$ At the same time, looking back at the history of financial sector booms and busts, we must conclude that variations are enormous and not entirely corresponding with what would have been intuitively forecast from the evidence of the past experience or on the basis of rational expectations. $^{38}$

Referring to the Figure 1, we may see that in 2005 the insurance sector and credit granting contributes to the finance GDP the most, while trusts and funds the least. Likewise, financial assets linked to them have the highest proportion, and therefore show the lowest unit productivity.

\footnotetext{
${ }^{37}$ Pooling of resources is typical in all productive companies, but differs according to their size. Despite the existence of number of financial instruments that enable pooling and channeling, many businesses find it less attractive as they are able to manage their cash reserves through their own capacities. For this they typically create an internal banking system where borrowing and lending is being done to effectively manage available liquidity excess.

${ }^{38}$ On this account, Philippon (2008) asserts that "contrary to common wisdom, there is neither theoretical nor empirical support for the idea that total factor productivity growth in the non financial sector has a direct influence on the size of the financial sector." This is also quite visible from the Figure 6 in the Appendix part of this first article.
} 
Figure 1: Allocations within the financial sector; 1=100\% (2005)

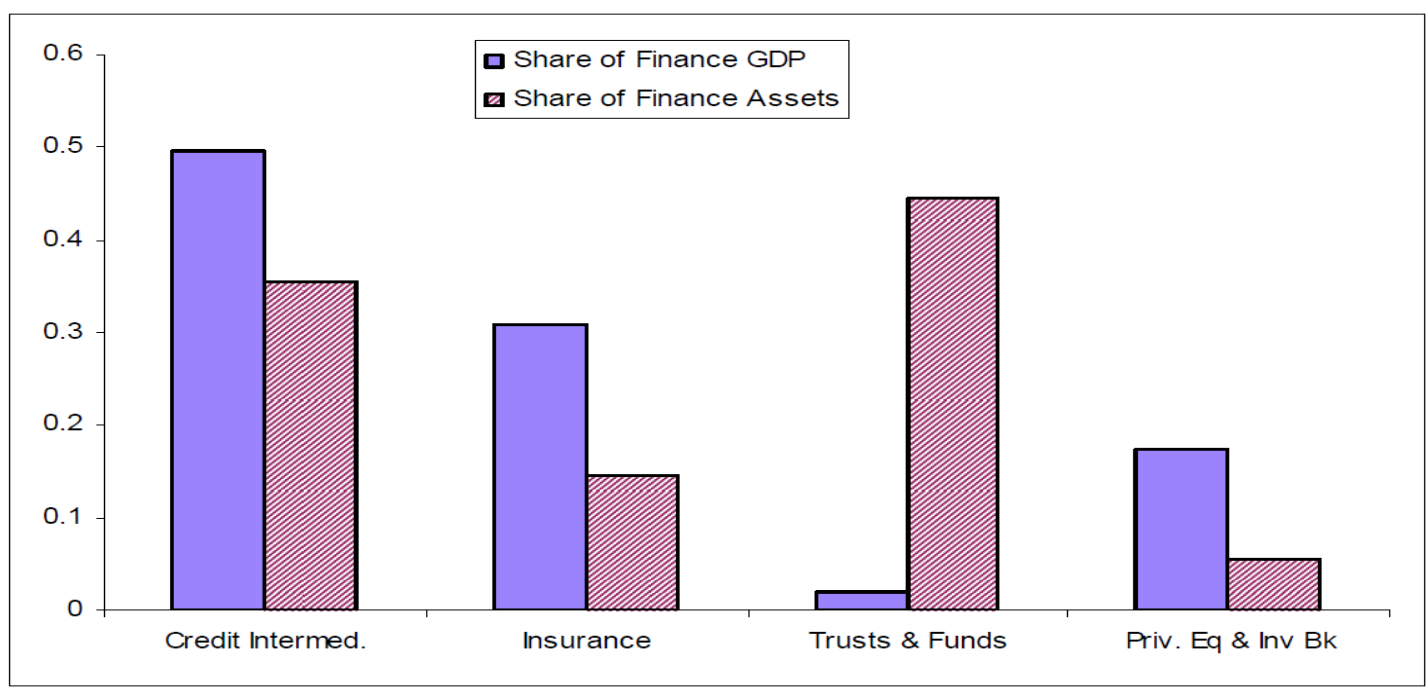

Legend: "Credit Intermed." stands for credit intermediation; "Priv. Eq \& Inv Bk" stands for private equity and investment banking.

Source: Philippon, 2008

In the Figure 2 we may observe that it was mostly credit intermediation whose value added increased (in terms of financial GDP) most abruptly. All presented branches apparently heightened their absolute and relative shares in the economy, but surprisingly enough, the finance value added of pension and open and closed mutual funds as well as unit investment trusts remained rather modest. A typical recent feature is that credit intermediation brings about high finance value added, but this is also true for investment banking and brokerage. All of these branches are idiosyncratic with far-reaching innovative activities that in turn inflate not only their relative shares but equally their financial value added. ${ }^{39}$

\footnotetext{
${ }^{39}$ This may clearly initiate more volatility as more value added will have to be created, while being serviced by a lower relative productive basis.
} 
Figure 2: GDP shares of finance industries

(1977-2006)

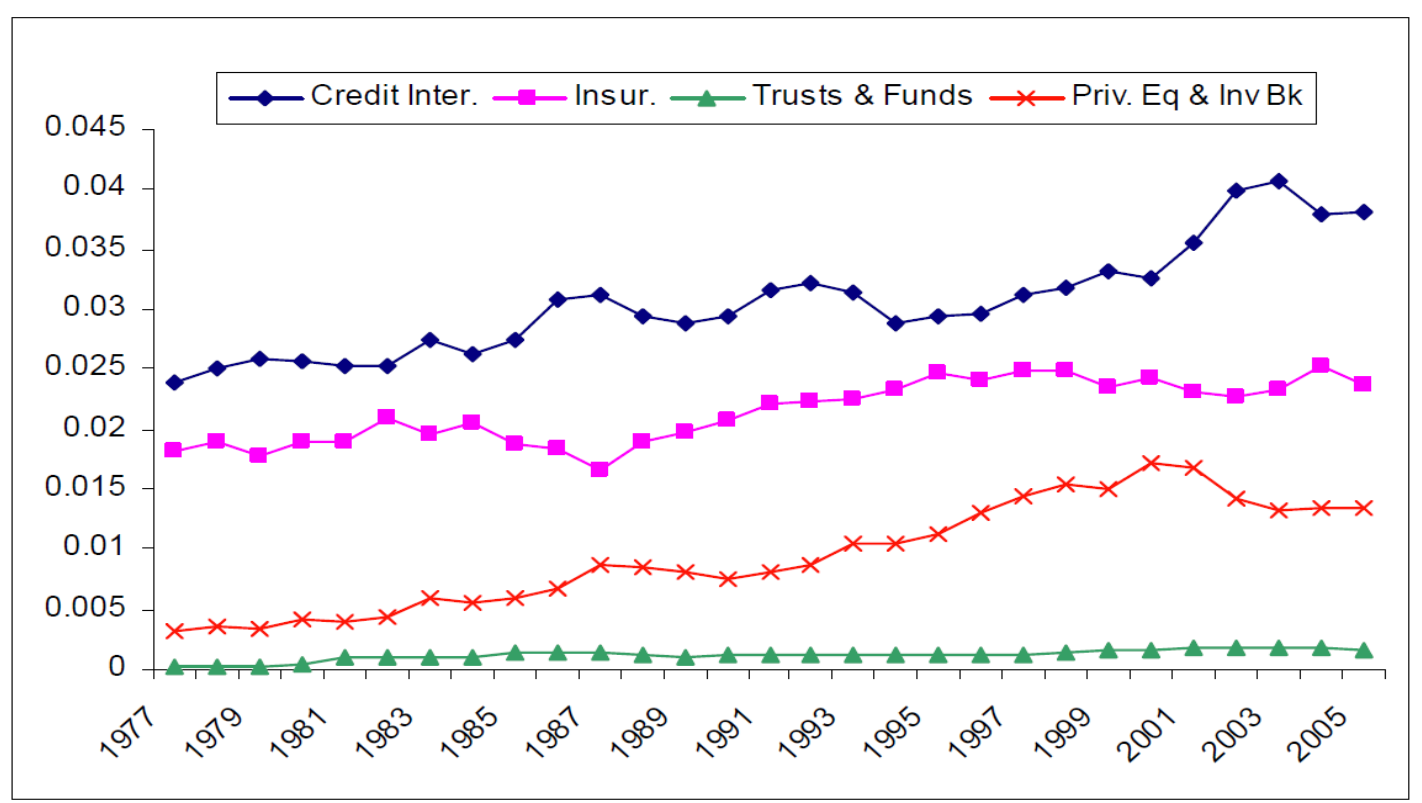

Legend: "Credit Inter." stands for credit intermediation; "Priv. Eq. \& Inv Bk" stands for private equity and investment banking.

Source: Philippon, 2008

If we now consider the aggregate value added, all this must inevitably translate into an ever-increasing share in the economy. Although a US case is presented, very similar trend is observable in most OECD countries ${ }^{40}$, despite the fact that some methodological discrepancies may occur due to a different legal framework regulating specific types of financial industry branches.

\footnotetext{
${ }^{40}$ Whereby, this similarity is more pronounced with resembling GDP per capita level as well as with the level of economic development of the respective member state. However, the US financial sector remains much above the OECD average in terms of its relative importance.
} 
Figure 3: Financial sector and insurance as a share of gross domestic product in the US (ratio to GDP; 1850-2010)

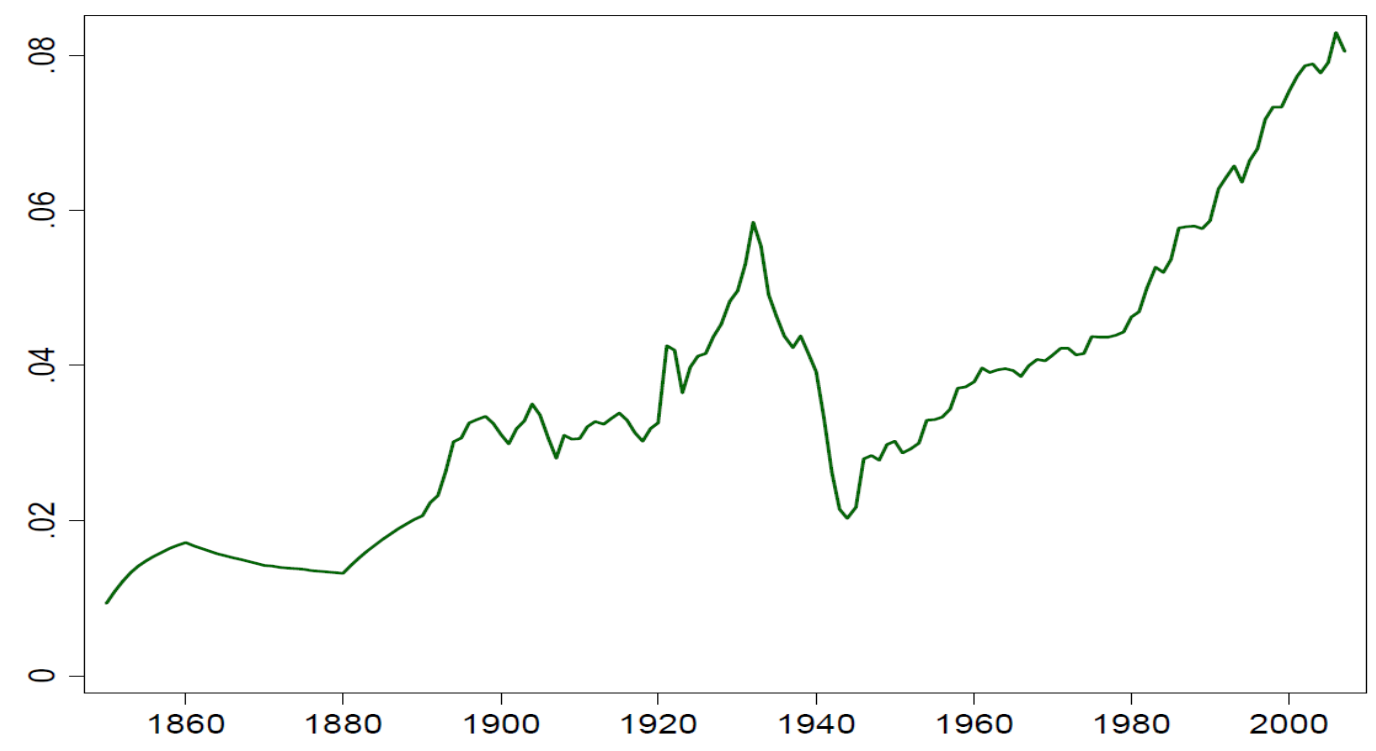

Source: Krohn, 2011

A very resembling picture can be recorded if employment is taken into account. Steadily increasing number goes hand-in-hand with both relative GDP share as well as increasing finance value added. This also maps into the fact that clerical employment has decreased over some recent time; therefore the evolution since the 1990s does not completely correspond with the evolution of value added in the industry. One can perhaps assume many other professions are henceforth connected with the industry, without being necessarily perceived as genuinely "financial". 41

\footnotetext{
${ }^{41}$ This could be for instance the case for IT specialists, programmers or PR and marketing analysts. Nevertheless, it would be perhaps extremely difficult to extract underlying data that would reflect this lemma more accurately.
} 
Figure 4: Employment in financial sector and insurance in the US (in percentage of total employment; 1948-2008)

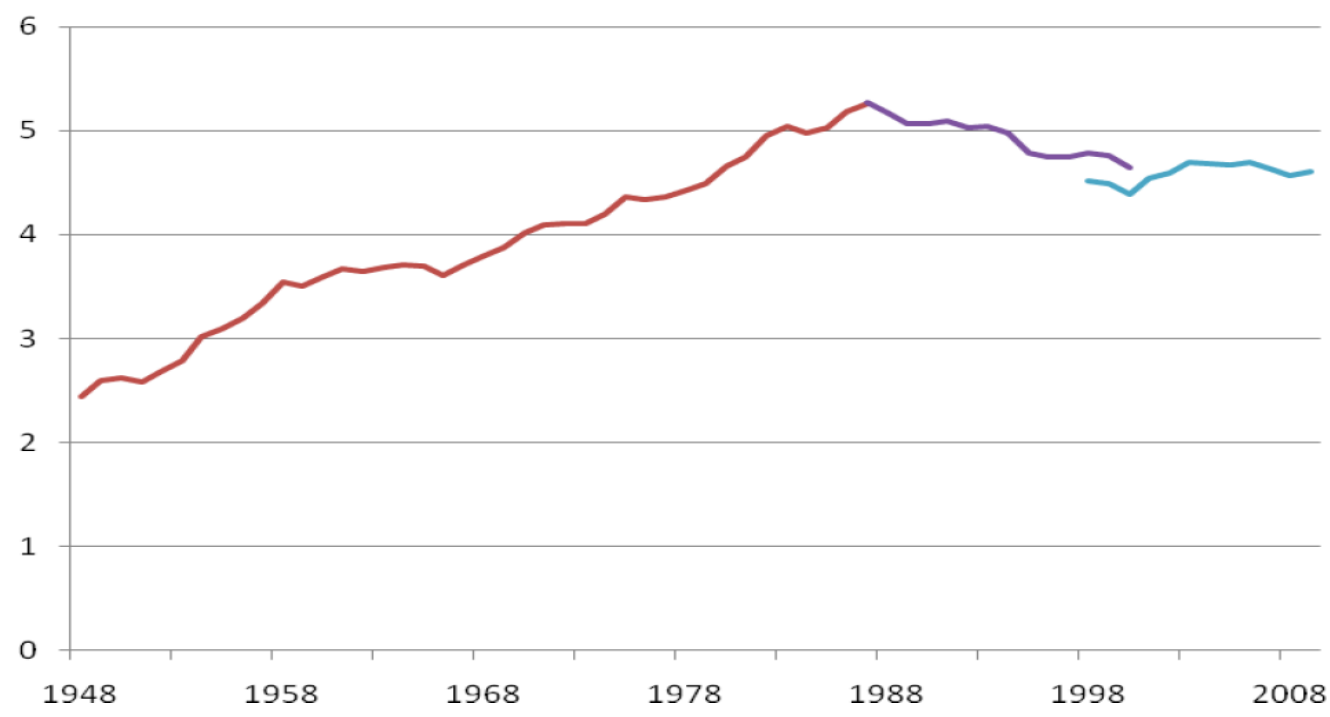

Source: Philippon, 2008

All this clearly shows that the recent evolution of financial intermediation goes far beyond what would be expected from purely economic perspective. Higher complexity of financial assets and surging OTC transactions may be one of the reasons for large portion of financial assets under financial sector management. This in turn creates a future raison d'être for at least some part of the financial industry. ${ }^{42}$ The only question is how much this asset servicing could be disconnected from real economic variables and eventually for how long.

One of the very first thorough critiques of the role of financial innovation dates back to the period of the Great Depression. Until the beginning of the 1920s most activities of the private sector had been financed by bank loans, if not by their proper resources. Clearly, bank credit has a big advantage compared to other forms of financing: a bilateral character. In other words, it is obvious who plays the role of a creditor and who plays the role of a debtor, which is in fact determined by the signed agreement and the following bilateral interaction between the agents involved. Yet, in 1922 a quiet revolution came in, bringing about new forms of financing. Since then the capital markets gained on importance and various financial products such as obligations and other financial assets started to play a very important role. Obviously, their complexity was still much lower in comparison to modern derivates such as institutionalized futures or non-institutionalized forwards. (Partnoy, 2010)

\footnotetext{
${ }^{42}$ It could well be the part with significant assets share possession.
} 
At the same time, number of financial intermediaries were also created, namely in order to facilitate movement of resources amongst enterprises. This creation precipitated a transition from conservative financing to a less conservative one and launched a wave of financial speculations. ${ }^{43}$ Many authors claim that the unprecedented increase of financial products destined for ordinary financing amplified the Great Depression as it "enabled" the companies to conceal their financial statements and balances. This kind of camouflage made the role of Fed much more difficult, since the latter was not able to react in a timely manner. Hence, even though Fed's role was more marginal than nowadays, it did not succeed to reduce the newly created bubble. (Merton, 1992; Baskin and Miranti, 1997, etc.)

Consequently, the development of the rating agencies, that followed the incipient Depression, was meant to weaken circumventions of existing regulatory framework, by the means of evaluating the private sector companies based on their credit capacity and payment behaviour. However, this kind of assessment led inevitably to a possibility of influencing the involved companies by the banks themselves, and ultimately issued in the principal-agent type of problem. Furthermore, banks had a tendency to acquire the most risky assets possible, as the better rated ones bore only mediocre returns. ${ }^{44}$ (Fraine and Mills, 1961) Somewhat more prudent approach was restored only when the economy had to experience yet another downward correction.

The genuine expansion of the financial sector is typical mainly of the 1970s, 1980s and partially also for the 1990s, when many instruments merging the risk came into existence. This is equally called a Golden Era of financial derivatives - instruments that had not been widely known before, but that began their tour de force immediately after they were publicly introduced. ${ }^{45}$ At the same time, increasing mathematization and, in general, quantification in economics, finance, and related disciplines, made many economists search for constrained optimization solutions at all costs. (Crawford and Sen, 1996) Besides this, the above-average salaries in financial advisory industry attracted many excellently educated people, who had or would have normally worked in physics, mathematics, engineering or IT industries, for example. ${ }^{46}$ This has logically spanned a mathematical spiral and caused a hike in

\footnotetext{
${ }^{43}$ By speculative activities we typically mean activities aiming at gaining short-term profits while undertaking substantial risks. The activities are often conditioned by accepting higher-than-normal leverage. This is also why the speculative capital is one of the fastest flowing types of liquidity. However, in many cases speculative capital may only be distinguished on ad hoc basis as its initial form is obviously different. Also, it is not always clear whether the speculative capital contributed to financial fluctuations or whether it has prevented higher financial cycle amplitudes. Even in this case the ad hoc approach is to be applied and possible lessons learnt drawn subsequently. In terms of statistics, according to Foster and Magdoff (2009) the number of overnight transactions with foreign currencies (in nominal terms) increased hundred-fold between 1977 and 2009 . It is certainly this kind of transactions that have very often something to do with genuine speculative capital activities.

${ }^{44}$ According to the authors, this was namely typical for investment banking.

${ }^{45}$ That is when the best-known financial derivatives came into existence and were almost unanimously treated as a great invention of the modern era.

${ }^{46}$ Similarly, some authors argue that regulators are exposed to a similar situation - in the sense that with an increasing sophistication of new instruments, their embanking becomes often impossible to fulfill. As a consequence, this can either lead
} 
yet existing information asymmetry between the providers and the consumers, i.e. between demand and supply side of the exchange. ${ }^{47}$ Moreover, such kind of imbalances bolstered up the status of the industry not only to the detriment of entrants, but also to the detriment of an indistinguishable mass of customers, conventionally called a "grey zone". In the longer run, generally speaking, it could even take away a non-negligible part of the consumer surplus in favour of the producer one, but may also lead to a significant inflation of asset bubbles.

It followed that the most elegant mathematical formulas, frequently based on multiple correlations, were able not only to offer some kind of scientific allure, but also a notion of preciseness and protection against diverse risks and riskiness. (Crawford and Sen, 1996) Instead of transferring these risks, the concomitant effect was to create them there where hardly anybody was able to expect them to ever occur. This is not that surprising as it may seem when we refer once again to a standard textbook on credit derivatives just as Crotty (2011) has done: "Even with a mathematical approach to handling correlation, the complexity of calculating the expected default payment, which is what is needed to arrive at a $C D O^{48}$ price, grows exponentially with an increasing number of reference assets [the original mortgages]. (...) As it turns out, it is hard to derive a generalized model or formula that handles this complex calculation while still being practical to use." (Chacko, Sjoman, Motohashi, and Dessain, 2006) Hence, it is relatively straightforward that under such circumstances no correct market pricing may be actually possible; i.e. no reflection of scarcity can take place - at least on a continuous basis. (Crotty, 2011)

\section{CONCLUSION}

The presented paper endeavored to discuss important facts and theories about financial innovation and its impact on financial stability and business cycle behavior. In the recent period, we have arrived at a relatively consensual approach towards financial innovation in modern economies, an approach which follows Post Keynesian, Regulationist, and partially also mainstream economic theories.

As has been argued, the general influence of financial innovation on consumer surplus can certainly be deemed positive (provided that elementary assumptions about consumers and consumer choice remain valid); the aggregate effect on macroeconomic stability is rather negative. This statement is underpinned by the constant violation of financial stability depending on the phase in which an economy

\footnotetext{
to a deficient regulation, or it may result in a regulation that is not appropriate given the particular state of world, and thus it is harmful for all parties involved.

47 The problem of information asymmetry in the lender - borrower relationship is skillfully and accessibly elaborated for instance in Janda (2006), Hanousek and Podpiera (2001) or alternatively, although less accessibly, in Inderst (2008).

${ }^{48}$ In financial economics, CDOs are typically referred to as collateralized-debt obligations. Such type of a security is usually backed by several assets that differ according to a number of characteristics. Subsequently, the differences are massed in tranches, while each tranche carries its specific degree of credit risk.
} 
finds itself. Hence, we are witnessing a "part for the whole situation", in which what may be seen as beneficial from a microeconomic point of view is not from an aggregate one (or a macroeconomic one). The main sign of this imbalance is the increased amplitude of the business cycle compared to periods in which the intensity of financial innovation was less pronounced. The mentioned economic streams differ significantly as to who or what is, in effect, the main cause of this instability.

From the perspective of recent developments, many mainstream economists have been forced to revise their position by making a quasi-U-turn. As a consequence, a number of measures aimed at curbing innovative activities in the financial sector as well as reintroducing financial stability have had to be approved and put in motion. These should also include the targeting of excessive behavior in both the expansionary and recessionary paths of the economy, avoiding thus a possible impact on long-term growth potential. As a result, for financial innovators and various intermediaries, it should be more difficult to bypass the regulatory framework in the economy. Even so, the problems of ad hoc efforts to regulate remain in place. One can perceive as very difficult to regulate the type of sectors with incomplete and often inaccurate information based on risks and dangers that are known not in advance and never fully experienced before.

The financial sector is very creative, productive and almost irrepressible with respect to innovative activity. This gives it an edge before all regulatory institutions ex definitio. However, as Gaston Berger, a Perspectivist School adherent, put it, "the faster you drive the further your headlights must shine". Clearly, much research is still needed in this field because the non-existent constraint on financial innovation can be a source of instability in both financial and macroeconomic systems

\section{REFERENCES}

AGLIETTA, M. 2009. La sortie de la récession promet d'être lente. http://www.alternativeseconomiques.fr/michel-aglietta----la-sortie-de-la- fr art 838 42525.html

(cited on 14/12/2011)

AGLIETTA, M. 1998. Le capitalisme de demain. Note de la Fondation Saint-Simon, 1998.

AGLIETTA, M. 2008. Macroéconomie financière. La découverte, Paris : collection Repères, 2008.

AGLIETTA, M. 1976. Régulation et crises du capitalisme. Paris : Calmann-Lévy, 1976.

AMABLE, B. 2005. Les cinq capitalismes. Paris : Seuil, 2005.

ANDERSON, W.L. 2003. Recovery or Boomlet? Mises Institut. http://mises.org/daily/1265 (cited on 6/1/2012).

ANDERSON, W.L. 2001. The Party is Over. Mises Institut. http://mises.org/daily/617 (cited on 6/.1/2012).

BASKIN, J.B., MIRANTI, P.J. JR. 1997. A History of Corporate Finance. N.Y.: Cambridge University Press, 1997. 
BANQUE DE FRANCE. 2011. http://www.banque-france.fr/la-banque-de-france/actualites.html (cited on $18 / 12 / 2011)$.

BEAMS, N. 2004. Greenspan testimony points to deepening US fiscal crisis. http://www.wsws.org/articles/2004/feb2004/gpan-f16.shtml (cited on 2/1/2012).

BERNANKE, $\quad$ B. $2004 . \quad$ The Great Moderation. http://www.federalreserve.gov/boarddocs/speeches/2004/20040220/default.htm (cited on 19/12/2011).

BEZEMER, D.J. 2009. "No One Saw This Coming": Understanding Financial Crisis through Accounting Models. Munich Personal RePEc Archive Paper, 2009.

BOYER, R. 2000. Is a financial-led growth regime a viable alternative to fordism? A preliminary analysis. Economy and society, Vol. 29, № 1, pp. 111-145.

BOYER, R. 2004. Théorie de la régulation, 1. Les fondamentaux. Paris : La découverte, collection Repères, 2004.

BOYER, R., DEHOVE, M., PLIHON, D. 2004. Les crises financières. Paris : La Documentation Française, 2004.

BOYER R., MISTRAL J. 1978. Accumulation, inflation, crises. Paris : PUF, 1978.

CRAWFORD, G., SEN, B. 1996. Derivatives for Decision Makers. N.Y.: John Wiley, 1996.

DUFFIE, D., JACKSON, M. 1989. Optimal Innovation of Futures Contracts. Review of Financial Studies, Vol. 2, No. 3, pp. 275-296.

DUMÉNIL, G., LÉVY, D. 2000. Crise et sortie de crise. Ordre et désordres néolibéraux. Paris : Presses Universitaires de France, 2000.

DUMÉNIL, G., LÉVY, D. 2006. La finance capitaliste: rapports de production et rapports de classe In : La finance capitaliste, Paris : Presses Universitaires de France, 2006.

FED. 2011. http://www.federalreserve.gov/ (cited on 18/12/2011).

FREIXAS, X., ROCHET, J.-C. 1997. Microeconomics of Banking. Cambridge: MIT Press, 1997.

FRAINE, H.G., MILLS, R.H. 1961. Effects of Defaults and Credit Deterioration on Yields of Corporate Bonds. The Journal of Finance, Vol. 16, No 3, pp. 423-434.

GERTLER, M., KIYOTAKI, N. 2010. Financial Intermediation and Credit Policy

in Business Cycle Analysis. In: Friedman, B.M., Woodford, M. (ed.) Handbook of Monetary Economics, chapter 11, pp. 547-599, 2010.

HILFERDING, R. 1910. Le capital financier. Étude sur le développement récent du capitalisme. Paris : Éditions de Minuit, 1910 (1970).

KEYNES, J.M. 1936. The General Theory of Employment, Interest and Money. Orlando, Florida: HBJ Edition, 1936 (1964).

KROHN, G.A. 2011. The Rise and Evolution of the Financial Sector in the United States.

(Prepared for the Workshop in Macroeconomic Research at Liberal Arts Colleges, held at Vassar College). http://blogs.vassar.edu/macroworkshop/files/2010/11/Paper-GregoryKohn.pdf (cited on $22 / 12 / 2011$ ).

LAVOIE, M. 2004. L'économie postkeynésienne. Paris: La découverte, collection Repères, 2004.

LUCAS, R.J. $2003 . \quad$ Macroeconomic Priorities. http://home.uchicago.edu/ sogrodow/homepage/paddress03.pdf (cited on 19/12/2011). 
MERTON, R.C. 1992. Financial innovation and economic performance. Journal of Applied Corporate Finance, 4 (4), pp. 12-22.

MILLER, M.H. 1986. Financial innovation: The last twenty years and the next. Journal of Financial and Quantitative Analysis, 21 (4), pp. 459-471.

MINSKY H. 1975. Financial instability, the current dilemma, and the structure of banking and finance. In: Compendium of Major Issues in Bank Regulation. Washington D. C.: U.S. Government Printing Office.

MINSKY H. 1967. Money, other financial variables, and aggregate demand in the short run. In: Horwich, G. (ed.) Monetary Process and Policy. Homewood, Illinois: Richard D. Irwin.

MINSKY H. 1986. Stabilizing an unstable economy. New Haven: Yale University Press, 1986.

OECD

STATISTICS.

2011.

http://www.oecd.org/document/0,3746,en 26492011854646275911111 1,00.html

(cited on $18 / 12 / 2011)$.

PARTNOY, F. 2009. Historical Perspectives on the Financial Crisis: Ivar Kreuger, the Credit-Rating Agencies, and Two Theories about the Function, and Dysfunction, of Markets. San Diego Legal Studies Paper, No. 10-009, pp. 431-443.

PAUL, R. 2000. A Republic, If You Can Keep It. http://www.todaysamericandream.com/rp republicifyoucankeep.html (cited on 3/1/2012).

PHILIPPON, T. 2008. The Evolution of the US Financial Industry from 1860 to 2007: Theory and Evidence. NBER Working Paper Series No. 13405.

ROCHON, L.-P. 1999. Credit Money and Production: An Alternative Post-Keynesian Approach. Cheltenham: Edward Elgar, 1999.

SANDLEBEN, G. 2003. Nationalökonomie und Staat. Zur Kritik der Theorie des Finanzkapitals. Hamburg: VSA-Verlag, 2003.

SENNHOLZ, H.F. 2002. The Fed is Culpable. http://mises.org/daily/1089 (cited on 3/1/2012).

SHILLER, R. 2009. In defence of financial innovation. Financial Times. http://www.ft.com/int//cms/s/0/c4a74ba2-ab83-11de-9be4-00144feabdc0.html\#axzz1 iofAeCL1 (cited on 11/12/2011)

SCHRIEDER, G., HEIDHUES, F. 1995. Reaching the poor through financial innovations. Quarterly Journal of International Agriculture, 34(2), pp. 132-48.

SUMMERS, P. 2007. What caused the 'Great Moderation'?: International evidence from a regime switching model with time-varying transition probabilities. Economic Review, Federal Reserve Bank of Kansas City, 2007.

TUFANO, P. 2002. Financial Innovation. Boston, Massachusetts: Harvard Business School (Draft version), 2002

WOLFSON, M. 1996. A Post Keynesian theory of credit rationing. Journal of Post Keynesian economics, Vol. 18, pp. 443-470. 